\title{
Sexual dimorphism and associated population characteristics in the benthopelagic shrimp Pasiphaea sivado (Crustacea: Caridea: Pasiphaeidae)
}

\author{
Daniela Silveira Simão ${ }^{1}$, José Luís Pérez Gil ${ }^{2}$, Pere Abelló ${ }^{1}$ \\ ${ }^{1}$ Institut de Ciències del Mar, CSIC, 08003 Barcelona, Catalonia, Spain. \\ (DSS) (Corresponding author) E-mail: danielassim@ gmail.com. ORCID iD: http://orcid.org/0000-0002-4724-8236 \\ (PA) E-mail: pabello@icm.csic.es. ORCID iD: http://orcid.org/0000-0001-6034-2465 \\ ${ }^{2}$ Centro Oceanográfico de Málaga, Instituto Español de Oceanografía, Fuengirola (Málaga), Spain. \\ (JLPG) E-mail: joseluis.perez@ ma.ieo.es. ORCID iD: http://orcid.org/ 0000-0002-1684-0210
}

\begin{abstract}
Summary: Morphological and size dimorphism between genders of the benthopelagic shrimp Pasiphaea sivado are reported for the first time in the present work. All five pleopod protopods of females are thinner and more elongated than the male pleopod protopods, which in turn are anteriorly rounded and have robust shapes. The shape variability of the second pleopod protopods was also analysed using geometric morphometrics techniques which clearly differentiated between the thinner, elongated shape of the females and the robust shape of males. An important application of the observations of sexual dimorphism in pleopod shape in adult $P$. sivado is, from now on, the ability to quickly assess the gender of individuals when fisheries and population biology studies are carried out in the field unaided by a magnifying. A critical size from which the population sex ratio biases changed from female to male dominance was found in all studied western Mediterranean populations of $P$. sivado. This critical size different and became progressively smaller from populations in the Alboran Sea to populations in the Catalan Sea. Concerning sex ratio, no significant tendency of gender segregation was found across the bathymetric distribution range of the species, suggesting that this species does not perform differential depth distribution by gender.
\end{abstract}

Keywords: geometric morphometrics; size dimorphism; population size structure; size at maturity; sex ratio, sex identification, juvenile size.

Dimorfismo sexual y características poblacionales asociadas en el camarón bentopelágico Pasiphaea sivado (Crustacea: Caridea: Pasiphaeidae)

Resumen: Se estudia por vez primera el dimorfismo sexual morfológico y de talla en el camarón bentopelágico Pasiphaea sivado. Los cinco protopodios de los pleópodos de las hembras son más esbeltos y alargados que los de los machos, los cuales son redondeados anteriormente y de aspecto más robusto. La variabilidad de forma de los protopodios de los segundos pleópodos se ha analizado mediante técnicas de morfometría geométrica, las cuales diferenciaron claramente las formas esbeltas y alargadas de las hembras respecto a las de los machos. Una importante aplicación práctica de estos resultados es que van a permitir una identificación rápida del sexo, sin auxilio de lupa, de los individuos adultos en estudios de pesquerías y de biología de poblaciones. Se identificó una talla crítica a partir de la cual los machos dominan significativamente su proporción en todas las poblaciones geográficas estudiadas en el Mediterráneo occidental. Esta talla es distinta y progresivamente menor desde las poblaciones más occidentales en el mar de Alborán hasta las más nororientales en el mar Catalán. Por lo que respecta a la proporción de sexos, no se detectó ninguna tendencia significativa a lo largo de la distribución batimétrica de la especie, lo que sugiere que la especie no lleva a cabo distribución diferencial entre machos y hembras en relación a la profundidad.

Palabras clave: morfometría geométrica; dimorfismo de talla; estructura de tallas poblacional; talla de madurez; proporción de sexos, determinación del sexo, talla juvenil.

Citation/Como citar este artículo: Simão D.S., Pérez Gil J.L., Abelló P. 2017. Sexual dimorphism and associated population characteristics in the benthopelagic shrimp Pasiphaea sivado (Crustacea: Caridea: Pasiphaeidae). Sci. Mar. 81(1): 57-66 doi: http://dx.doi.org/10.3989/scimar.04378.20A

Editor: J.A. Cuesta.

Received: November 24, 2015. Accepted: December 19, 2016. Published: January 31, 2017.

Copyright: () 2017 CSIC. This is an open-access article distributed under the terms of the Creative Commons Attribution (CC-by) Spain 3.0 License. 


\section{INTRODUCTION}

Pasiphaeid shrimps are a group of benthopelagic and pelagic species that currently comprises a total of 98 species grouped in seven genera: Alainopasiphaea (2), Eupasiphae (4), Glyphus (1), Leptochela (15), Parapasiphae (4), Pasiphaea (67), and Psathyrocaris (5) (De Grave and Fransen 2011, Komai et al. 2012). In particular, within the genus Pasiphaea up to four morphologically-related species groups have been recognized, including the Pasiphaea sivado group, to which a total of nine species belong (Hayashi 1999, 2006). Species of this family are distributed along a wide latitudinal range, from tropical to Arctic and sub-Antarctic waters, mainly on and above continental slopes and in the open sea, including deep-sea habitats (Clarke and Holmes 1987, Gibbons et al. 1994, Tavares and Cardoso 2006). Morphological features in this family, such as lateral compression of the body and pleopods, are considered to be the result of selective pressures of adaptation to the pelagic environment (Cartes et al. 1993, Johnsen 2005, Aguzzi et al. 2007). Notwithstanding the relatively large amount of systematics and faunistics work done on this family (e.g. Zariquiey Álvarez 1957, Iwasaki 1990, Hayashi 1999), there are still few detailed studies on biological aspects of species of this family. They refer mainly to the European species Pasiphaea sivado and Pasiphaea multidentata (Cartes 1993, Frank 2000, Ramirez-Llodra et al. 2007), but also to Pacific Ocean species such as Pasiphaea japonica and Leptochela gracilis (Nanjo 2007, Oh et al. 2006).

No reference is made to the occurrence of macroscopic differences in shape in relation to gender in this family (Zariquiey Álvarez 1968, Iwasaki 1990, Hayashi 1999), except for the noted occurrence of differences in pleopod shape in Pasiphaea japonica (Doi 1975, Nanjo and Ohtomi 2009). Concerning body size dimorphism, based on overall size frequency distributions, males have been reported to be slightly larger than females in $P$. sivado, and slightly smaller than females in $P$. multidentata (Company et al. 2001), but sexual dimorphism has so far been considered insignificant in both $P$. sivado nor $P$. multidentata.

We herein aim to report sexual dimorphism in $P$. sivado, quantify the occurrence of morphological dimorphism, and analyse size-related population structure and sex ratio in relation to geographic and bathymetric characteristics.

\section{MATERIALS AND METHODS}

Samples of $P$. sivado were collected during a series of demersal fisheries research cruises (MEDITS_ES) between 2004 and 2011 at depths of around 40 to 800 $\mathrm{m}$ along the Mediterranean coasts of the Iberian Peninsula (Bertrand et al. 2002). On these cruises, $P$. sivado was only collected at depths of 150-750 m (Abelló et al. 2002). All $P$. sivado individuals were sexed by checking the presence/absence of appendix masculina on the endopod of the second pleopod, as is usual in caridean shrimps.

\section{Pleopod morphology}

For morphometric analyses, ten adult specimens of Pasiphaea sivado (five males and five females) were selected from a sample taken by demersal trawling in the western Mediterranean Sea (Alboran Sea: $36.4908^{\circ} \mathrm{N}, 4.2885^{\circ} \mathrm{W}$ ) at $424-428 \mathrm{~m}$ depth during daytime on $17 / 05 / 2010$. The haul was performed on board the R/V Cornide de Saavedra at a speed of 3 knots for $1 \mathrm{~h}$ using a demersal GOC-73 otter trawl with a 2.5- to 3.0-m vertical opening and a codend stretched mesh size of $20 \mathrm{~mm}$ (Fiorentini et al. 1999). The cruise was part of the MEDITS_ES project (Bertrand et al. 2000, 2002).

The selected specimens had a cephalothorax length (CL) $>18 \mathrm{~mm}$ and were clearly morphologically considered as adults (Company et al. 2001, present observations). CL was measured using a digital calliper rule with a precision of $0.01 \mathrm{~mm}$. Sizes of the examined specimens ranged between 18.8 and $23.5 \mathrm{~mm} \mathrm{CL}$ in females, and between 21.6 and $24.0 \mathrm{~mm}$ CL in males.

In order to graphically show the a priori differences observed between genders, one adult male and one female of similar size were figured and measured. In a first step, the external view of all five right pleopod protopods of each individual were drawn using a camera lucida coupled to a Leica MZ12 magnifier provided with an ocular micrometer. After that, the length and maximum width of the rest of the individuals were measured to obtain a first index of pleopod shape based on the ratio between these perpendicular measures.

\section{Geometric morphometrics}

To further assess the occurrence of sexual dimorphism using geometric morphometric techniques, pictures were also taken from the same external view of the right second pleopod of all five males and females selected using the same magnifier, which had an integrated Leica DC100 video camera and a DC200 digital imaging system. The first landmark was placed on the dorsal maximum convex curvature of the protopod, the second and fourth were placed at the anterior maximum curvature where the exopod and endopod are inserted in the protopod, the third at the maximum concavity between these two landmarks, the fifth at the maximum perpendicular width of the protopod in relation to the first landmark, the sixth at the ventral maximum curvature in the posterior part of the protopod and the seventh at the maximum concave curvature on the posterior dorsal margin of the protopod (Fig. 1).

Using Tps.Dig2 v2.16 software (Rohlf 2010a), the $x, y$ coordinates of the landmark dataset were obtained. Generalized procrustes superimposition analysis was performed to align and to eliminate scale and orientation distortions before shape analysis using tpsRelw v1.49 software (Rohlf 2010b). Statistical analysis of shape variance was assessed using the MorphoJ software (Klingenberg 2011). We then applied procrustes ANOVA, which is a two factorial ANOVA that performs analysis of both size (univariate) and shape (multivariate). This procedure is therefore a useful 


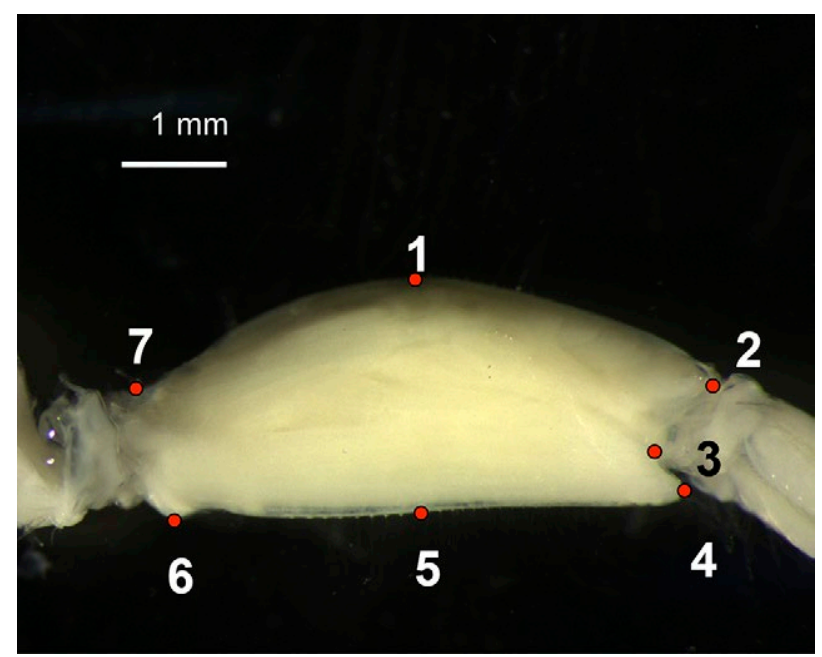

Fig. 1. - Landmark positions in the digital images obtained with stereoscope using a 16x magnifier with optical zoom. The width and length of each Pasiphaea sivado pleopod protopod were measured from the scalar distance (in $\mathrm{mm}$ ) between the landmarks 1-5 and 4-6, respectively.

method for discovering localized variation (Klingenberg and McIntyre 1998). Finally, a principal component analysis (PCA) was applied to quantify the contribution of the principal factor of landmark displacement that explains the shape variance between genders. This PCA was run using the covariance matrix generated from shape variation components, which were previously derived from the coordinates landmark dataset, pooled within-group with sex as a covariate (Viscosi and Cardini 2011).

\section{Gender assignment by visual inspection}

We assessed the power of telling apart the gender in adult individuals by just visual observation, since this would facilitate sex identification in field work. A total of 187 individuals of sizes comprised between 8 and 24 mm CL were visually examined for sex identification based on pleopod morphology during one fishery research cruise. Three volunteers were asked to identify the sex visually based on the information provided by the morphological drawings obtained in the section on pleopod morphology. A posteriori one of the authors checked whether each assignation was correct based on the presence of appendix masculina under a stereoscope microscope, as usually performed for caridean shrimps. The proportion of correct assignation by size class was then calculated.

\section{Gender differences in size and sex ratio}

Sex ratio, as the proportion of males, was calculated within each $1 \mathrm{~mm}$ CL size class separately for samples taken in the Alboran Sea (the westernmost basin of the Mediterranean Sea), the intermediate Alacant area (between Cape Palos and Cape La Nao) and the Catalan Sea (in the NW Mediterranean). These sectors were established according to previous results (Simão et al. 2015), in which differences in size at maturity were observed between Alboran Sea populations and the rest of the sampled populations along the Iberian Peninsula Mediterranean coasts. Sex ratio was not calculated in size classes with fewer than 25 individuals. The significance of the deviation from an expected 1:1 sex ratio was calculated using a heterogeneity G-test (Sokal and Rohlf 1981, Abelló et al. 1990). The relationship of sex ratio with depth was also calculated; only samples containing more than 25 sexed individuals larger than 15 $\mathrm{mm}$ CL were considered for this analysis; this cut-off size was chosen to ensure that sex ratio was calculated over adult specimens to minimize error in gender assessment (see below), and also to encompass the whole adult cohort as visually assessed through size frequency distributions.

In order to verify whether size frequency distributions (SFDs) differed between geographic populations and between depth strata, the Kolmogorov-Smirnov test within VITMAN fisheries software (Lleonart and Salat 1992) was used. Combinations of geographic area and depth strata resulting in less than 100 individuals measured (i.e. at both extremes of the bathymetric range of the species in each area) were not used in the analyses.

\section{RESULTS}

A total of $4010 P$. sivado individuals were sexed and measured. This allowed the assessment of any size-related differences between genders. These specimens were sexed as usual for caridean shrimps (i.e. by checking the presence of appendix masculina). In the present work, males were classified as juveniles when the appendix masculina was not fully formed but present as small buds. This was evident in individuals with sizes ranging between 9 and $16 \mathrm{~mm} \mathrm{CL}$. However, the proportion of individuals showing appendix masculina buds was very small at sizes smaller than 11-12 mm CL, when it was probably still undeveloped in a larger proportion of males, so gender could not be correctly assigned based on this character at these small sizes. Therefore, sex ratio analysis was restricted to individuals larger than $15 \mathrm{~mm}$ CL to ensure a higher reliability in properly assessing gender.

\section{Pleopod morphology}

The difference in protopod morphology between genders of Pasiphaea sivado was quite readily identified by sight (Fig. 2). Overall, in all five pleopod pairs, adult female protopods were clearly much thinner than those in adult males. Additionally, the anterior edge of the male protopods was clearly much more convex than in females, while the posterior edge was approximately straight in both males and females. As shown in Figure 3 , the ratio between pleopod protopod length and width (L/W), which can be considered a protopod thinness index, was much higher in females than in males, thus characterizing the thinner, rectangular, elongated shape in females versus the more robust shape present in males. A significant difference between genders was obtained for all five pleopod pairs (Table 1). Additionally, no setae were present on the anterior edge of the 


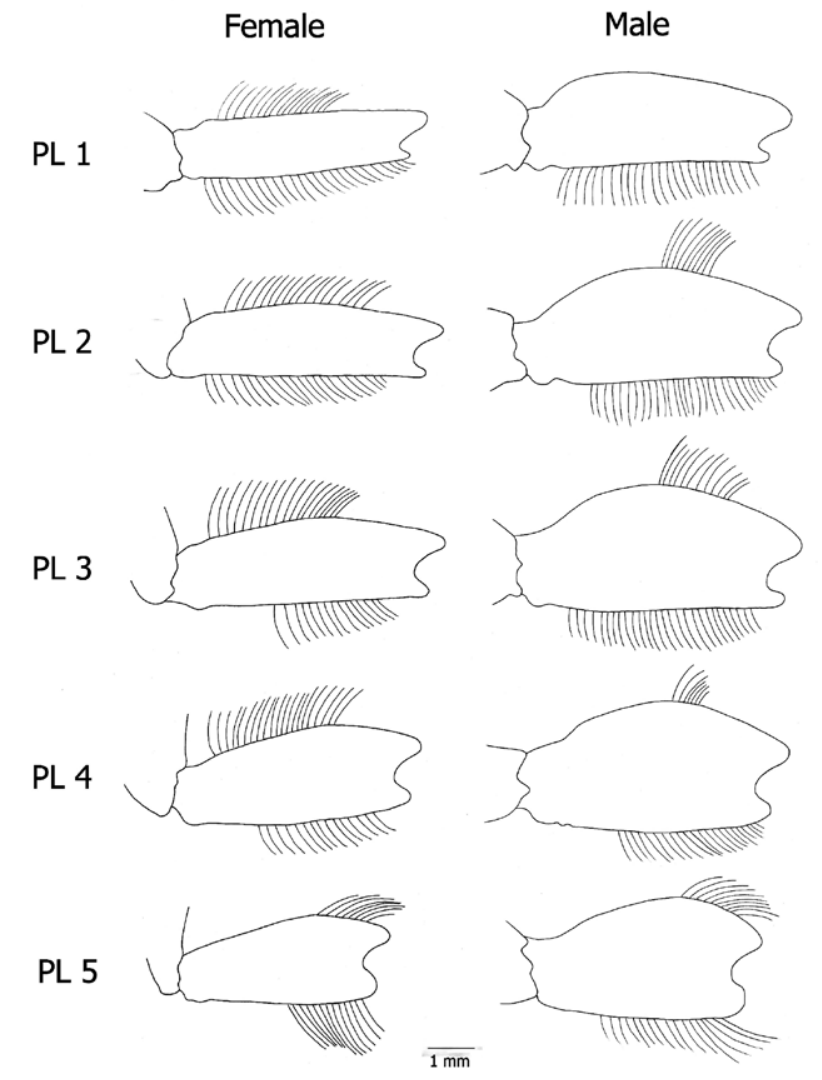

Fig. 2. - Lateral view of the protopods of each five right pleopods (PL) of a Pasiphaea sivado female with $22.7 \mathrm{~mm} \mathrm{CL}$ and of a male with $22.6 \mathrm{~mm} \mathrm{CL}$.

first pleopod protopod in any of the adult males examined, and in the rest of the pleopods anterior setae were much scarcer in males than in females.

The use of geometric morphometrics techniques further evidenced the differences between genders in pleopod protopod shape. Both $P$. sivado males and females grouped as two well-differentiated clusters in the analysis of the shape of their second pleopod protopods (Fig. 4A). The overall consensus shape (Fig. 4B) of the pleopod protopods, which is based on the geometric mean position of each landmark, clearly differentiated between the thinner, elongated shape of the females versus the broader shape found in males. PCA showed that the first principal component (PC1), which accounted for $56.1 \%$ of the total shape variability, clearly

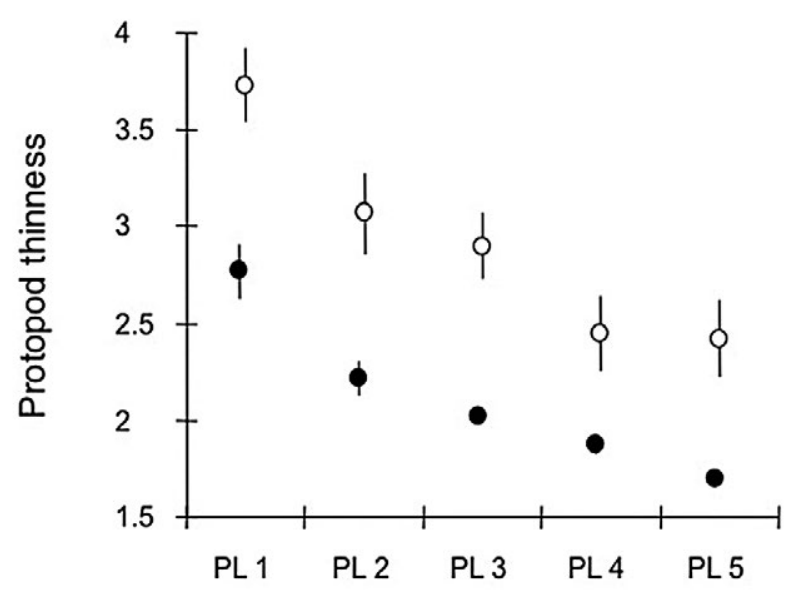

Fig. 3. - Mean pleopod (PL) protopod thinness index (length/width) ( standard error of the mean) of female (white circles) and male (black circles) Pasiphaea sivado.

A

PC 2

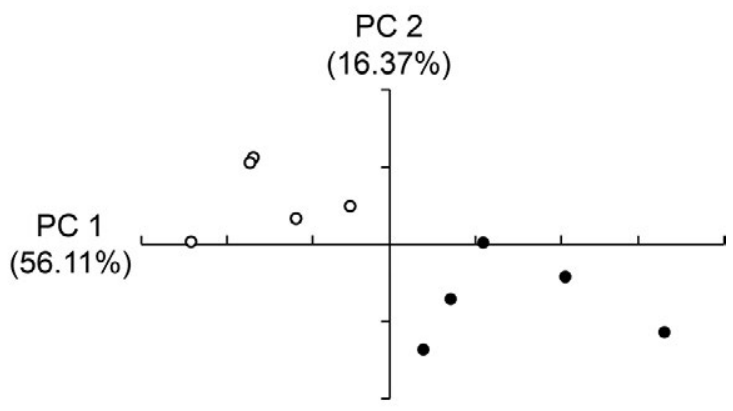

B

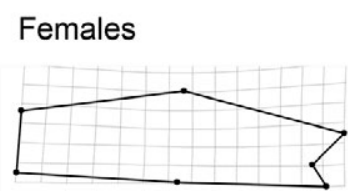

Males

Fig. 4. - A, shape variation analysis for Pasiphaea sivado adults: females (white circles); males (black circles). The contribution percentages of the two principal components are presented on each axis. B, thin plate consensus shapes for each gender.

differentiated males from females. The shape variance between genders explained by the $\mathrm{PC} 1$ was significantly different (ANOVA $F_{10,80}=27.24 \mathrm{p}<0.0001$ ) andwas not affected by the centroid size effect (ANOVA $\left.\mathrm{F}_{1,8}=1.87 \mathrm{p}=0.209\right)$. The next five principal compo-

Table 1. - Number of individuals examined $(\mathrm{N})$, mean, standard deviation $( \pm \mathrm{SD})$, maximum (max) and minimum (min) length $(\mathrm{L})$ and width (W) of the pleopod protopod (PL1-5, first to fifth), and mean ratio L/W of adult Pasiphaea sivado females $\left(\mathrm{CL}_{\text {range }}=18.8-23.5 \mathrm{~mm}\right)$ and males $\left(\mathrm{CL}_{\text {range }}=21.6-24.0 \mathrm{~mm}\right)$. Significance of differences of the $\mathrm{L} / \mathrm{W}$ ratio between genders is also shown in the the last column of the first table.

\begin{tabular}{|c|c|c|c|c|c|c|c|c|c|c|c|}
\hline & \multirow[b]{2}{*}{$\mathrm{N}$} & \multicolumn{4}{|c|}{ Length } & \multicolumn{4}{|c|}{ Width } & \multirow{2}{*}{$\begin{array}{l}\text { Mean } \mathrm{L} / \mathrm{W} \\
\text { ratio }\end{array}$} & \multirow{2}{*}{$\begin{array}{l}\mathrm{t} \text { Test } \\
\mathrm{p}\end{array}$} \\
\hline & & Mean & $\mathrm{SD}$ & Max & Min & Mean & SD & Max & Min & & \\
\hline \multicolumn{12}{|c|}{ Females } \\
\hline PL 1 & 4 & 4.65 & 0.38 & 5.0 & 4.1 & 1.25 & 0.14 & 1.4 & 1.1 & 3.73 & $\mathrm{p}<0.05$ \\
\hline PL 2 & 5 & 5.13 & 0.47 & 5.8 & 4.7 & 1.73 & 0.38 & 2.3 & 1.3 & 3.07 & $\mathrm{p}<0.02$ \\
\hline PL 3 & 5 & 4.97 & 0.38 & 5.5 & 4.5 & 1.79 & 0.41 & 2.4 & 1.4 & 2.90 & $\mathrm{p}<0.05$ \\
\hline PL 4 & 5 & 4.73 & 0.43 & 5.2 & 4.2 & 1.99 & 0.38 & 2.6 & 1.5 & 2.44 & $\mathrm{p}<0.05$ \\
\hline PL 5 & 4 & 4.19 & 0.40 & 4.5 & 3.6 & 1.73 & 0.20 & 1.9 & 1.4 & 2.42 & $\mathrm{p}<0.001$ \\
\hline \multicolumn{12}{|l|}{ Males } \\
\hline PL 1 & 5 & 4.89 & 0.22 & 5.2 & 4.6 & 1.79 & 0.22 & 2.0 & 1.4 & 2.76 & \\
\hline PL 2 & 5 & 5.09 & 0.09 & 5.2 & 5.0 & 2.33 & 0.22 & 2.5 & 2.0 & 2.21 & \\
\hline PL 3 & 5 & 5.08 & 0.36 & 5.6 & 4.8 & 2.52 & 0.16 & 2.8 & 2.4 & 2.01 & \\
\hline PL 4 & 5 & 4.86 & 0.30 & 5.3 & 4.5 & 2.60 & 0.09 & 2.7 & 2.5 & 1.87 & \\
\hline PL 5 & 5 & 4.16 & 0.23 & 4.4 & 3.8 & 2.46 & 0.16 & 2.7 & 2.3 & 1.70 & \\
\hline
\end{tabular}




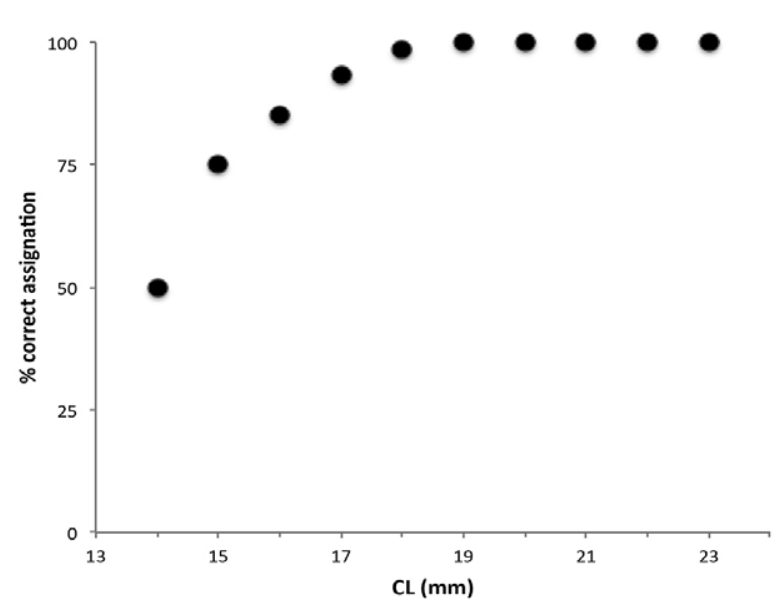

Fig. 5. - Percentage of correct gender assignation by size class in Pasiphaea sivado based on pleopod morphology observation with naked eye $(\mathrm{N}=542)$.

nents explained $16.5 \%, 10.4 \%, 6.2 \%, 3.5 \%$ and $1.26 \%$ of the total shape variance, respectively.

Regarding the visual sex assessment on board, a total of 542 gender assignations were made on the examined individuals by three independent observers. Figure 5 shows the percentage of correct sex identification by pleopod morphology based on independent visual assessment by all observers. Total reliability was attained in individuals larger than $18 \mathrm{~mm} \mathrm{CL}$, and the percentage of correct assignation decreased with decreasing size.

\section{Comparison of sizes and size-related sex ratio among geographic areas}

The overall SFDs of sexed individuals by geographic area (Fig. 6) were biased towards adult individuals in all populations. The Alboran Sea population showed a higher proportion of individuals in the largest sizes than in those obtained in the Alacant area and the Catalan Sea. The comparison between male and female SFDs within each area showed that they were not significantly different in any case (main diagonal in Table 2 ). The comparison of male or female SFDs among areas also showed non-significant values (Table 2).

The analysis of sex ratio by size class showed that in all sectors females were dominant at sizes smaller than around 18-19 $\mathrm{mm} \mathrm{CL}$, while the proportion of males was significantly higher at larger sizes, therefore evidencing the occurrence of a slight sexual size dimorphism in P. sivado (Fig. 6). When special attention was paid to the precise size at which the dominance of males occurred, a decreasing gradient was found in the study area, with the proportion of males being significantly higher at CL sizes larger than $21 \mathrm{~mm}$ in the Alboran Sea, $20 \mathrm{~mm}$ in the Alacant area and $19 \mathrm{~mm}$ in the Catalan Sea (Fig. 6).

\section{Size structure with depth by geographic area}

When the shape of the SFDs was analysed by depth strata, a high frequency of juveniles in relation to adults was evident in the shallowest depth stratum (200-300
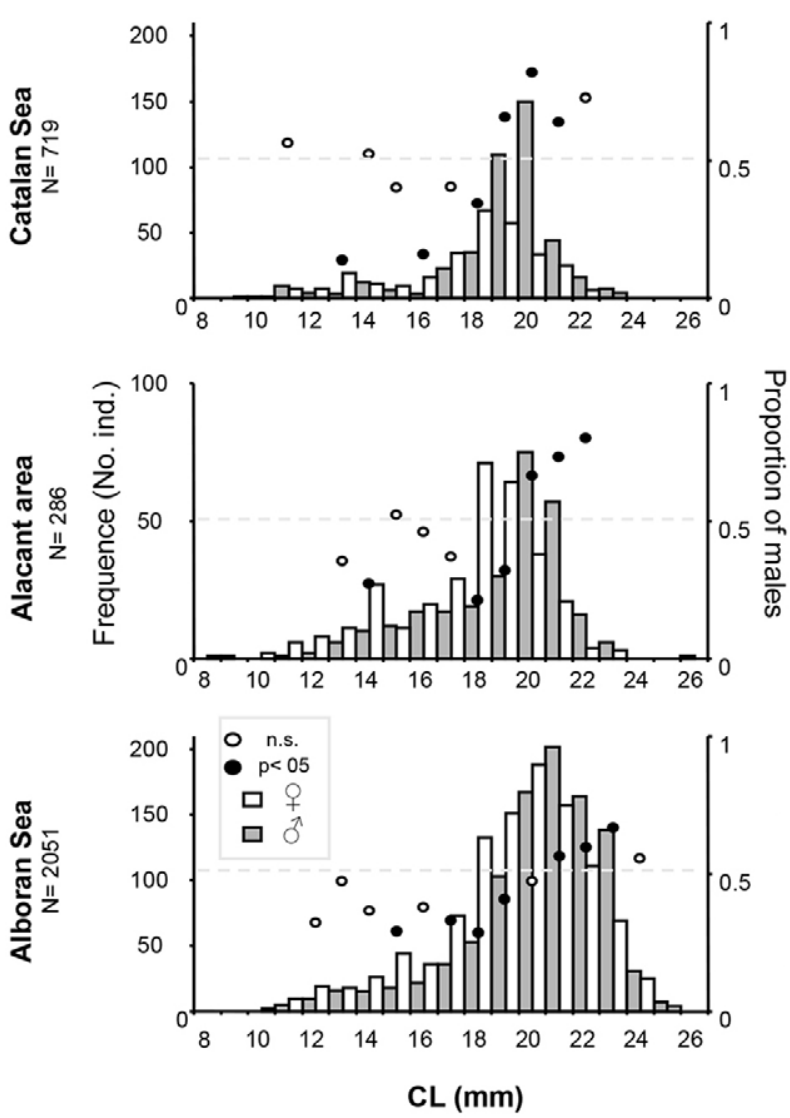

Fig. 6. - Size frequency distributions by sex in Pasiphaea sivado from the Alboran Sea, Alacant area and Catalan Sea geographic sectors; males grey bars and females white bars. The sex ratio, as a proportion of males, is represented by circles, with indication of values showing a significant $(\mathrm{p}<0.05$, dark circles) or non-significant (n.s., light circles) deviation from an expected 1:1 ratio. The total number of individuals analysed by geographic area is presented.

Table 2. - Comparison of size frequency distributions between geographic populations (Kolmogorov-Smirnov test). The $\mathrm{p}$ values for the comparison between females are presented above the diagonal, those between males below the diagonal, and those comparing males and females within each population along the main diagonal (values in italics).

\begin{tabular}{|c|c|c|c|c|c|}
\hline & & Alboran & Alacant & Catalan & \\
\hline Alboran & & 0.869 & 0.308 & 0.537 & q \\
\hline Alacant & & 0.522 & 0.263 & 1.000 & \\
\hline Catalan & 0 & 0.182 & 1.000 & 0.243 & \\
\hline
\end{tabular}

m), especially in the Alboran Sea (Fig. 7), where the population showed a marked SFD displacement towards larger sizes with increasing depth. No noticeable variation in SFD displacement was evident in the Alacant area and Catalan Sea populations (Fig. 7 and Table 3). The comparison of the SFDs with the Kolmogorov-Smirnov test showed the occurrence of significant differences by depth only in the Alboran Sea population, in both males and females (Table 4). No significant differences in SFD variation with depth were detected in the Alacant area and Catalan Sea populations. It is worth noting that despite intensive sampling, the densities of $P$. sivado at certain depths and areas are very low (Simão et al 2015): the species is hardly found shallower than $200 \mathrm{~m}$, except in the Alboran Sea, and deeper than $600 \mathrm{~m}$ throughout the study area. 


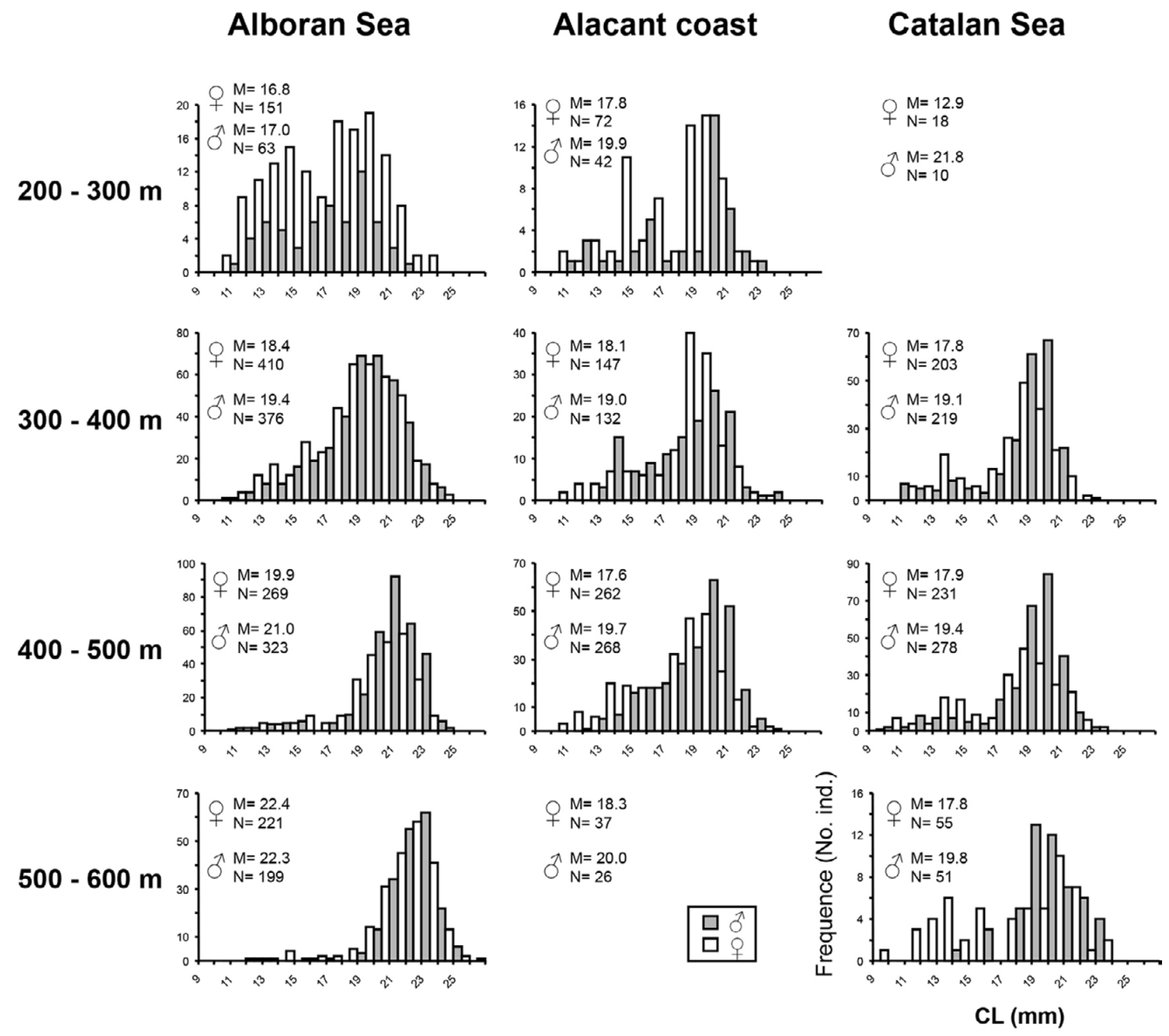

Fig. 7. - Size frequency distributions of male (dark bars) and female (white bars) Pasiphaea sivado by $100 \mathrm{~m}$ depth strata. The number of measured individuals by gender $(\mathrm{N})$ is shown. Strata with fewer than 100 measured individuals are not shown since the low number by sex was considered to be not relevant.

Table 3. - Comparison of median sizes (carapace length, CL; in $\mathrm{mm}$ ) among $100 \mathrm{~m}$ depth strata within each geographic population. The obtained Mann-Whitney p values for the comparison between females are presented above the diagonal, between males below the diagonal and between genders within each depth stratum along the diagonal (values in italics).

\begin{tabular}{|c|c|c|c|c|c|c|c|c|c|}
\hline & Median CL $\widehat{O}$ & Depth Strata (m) & & $200-300$ & $300-400$ & $400-500$ & $500-600$ & & Median CL + \\
\hline Alboran Sea & $\begin{array}{l}17.0 \\
19.4 \\
21.0 \\
22.3\end{array}$ & $\begin{array}{l}200-300 \\
300-400 \\
400-500 \\
500-600\end{array}$ & 0 & $\begin{array}{l}0.301 \\
0.000 \\
0.000 \\
0.000\end{array}$ & $\begin{array}{l}0.000 \\
0.000 \\
0.000 \\
0.000\end{array}$ & $\begin{array}{l}0.000 \\
0.000 \\
0.000 \\
0.000\end{array}$ & $\begin{array}{l}0.000 \\
0.000 \\
0.000 \\
0.000\end{array}$ & q & $\begin{array}{l}16.8 \\
18.4 \\
19.9 \\
22.4\end{array}$ \\
\hline Alacant area & $\begin{array}{l}19.9 \\
19.0 \\
19.7 \\
20.0\end{array}$ & $\begin{array}{l}200-300 \\
300-400 \\
400-500 \\
500-600\end{array}$ & $\sigma^{\lambda}$ & $\begin{array}{l}0.001 \\
0.298 \\
0.626 \\
-\end{array}$ & $\begin{array}{c}0.294 \\
0.004 \\
0.008 \\
-\end{array}$ & $\begin{array}{c}0.970 \\
0.083 \\
0.000 \\
-\end{array}$ & $\begin{array}{l}- \\
- \\
-\end{array}$ & q & $\begin{array}{l}17.8 \\
18.1 \\
17.6 \\
20.0\end{array}$ \\
\hline Catalan Sea & $\begin{array}{l}21.8 \\
19.1 \\
19.4 \\
19.8\end{array}$ & $\begin{array}{l}200-300 \\
300-400 \\
400-500 \\
500-600\end{array}$ & $\hat{\sigma}^{\lambda}$ & $\begin{array}{l}- \\
- \\
-\end{array}$ & $\begin{array}{c}- \\
0.000 \\
0.036 \\
0.001\end{array}$ & $\begin{array}{c}- \\
0.412 \\
0.000 \\
0.023\end{array}$ & $\begin{array}{c}- \\
0.030 \\
0.959 \\
0.000\end{array}$ & q & $\begin{array}{l}12.9 \\
17.8 \\
17.9 \\
17.8\end{array}$ \\
\hline
\end{tabular}

\section{Sex ratio with depth}

A total of 84 samples were used to analyse the sex ratio across the bathymetric distribution of the species
(Fig. 8). Most of the samples (70.2\%) did not show a significant deviation from a 1:1 sex ratio. However, sex segregation was identified in the rest of samples, with $11.9 \%$ of them being biased towards females 
Table 4. - Comparison of size frequency distributions by $100 \mathrm{~m}$ depth strata within each geographic population. The KolmogorovSmirnov $\mathrm{p}$ values for the comparison between females are presented above the diagonal, between males below the diagonal, and between genders along the diagonal (values in italics); significant values are shown in bold.

\begin{tabular}{|c|c|c|c|c|c|c|c|}
\hline & Depth (m) & & $200-300$ & $300-400$ & $400-500$ & $500-600$ & \\
\hline \multirow[t]{4}{*}{ Alboran Sea } & $200-300$ & & 1.000 & 0.650 & 0.061 & 0.000 & q \\
\hline & $300-400$ & & 0.278 & 0.931 & 0.685 & 0.013 & \\
\hline & $400-500$ & & 0.001 & 0.272 & 0.517 & 0.184 & \\
\hline & $500-600$ & $\hat{\jmath}$ & 0.000 & 0.004 & 0.171 & 0.830 & \\
\hline \multirow[t]{4}{*}{ Alacant area } & $200-300$ & & 0.105 & 0.978 & 1.000 & - & 우 \\
\hline & $300-400$ & & 0.957 & 0.687 & 1.000 & - & \\
\hline & $400-500$ & & 0.997 & 1.000 & 0.208 & - & \\
\hline & $500-600$ & $\hat{\jmath}$ & - & - & - & - & \\
\hline \multirow[t]{4}{*}{ Catalan Sea } & $200-300$ & & - & - & - & - & 우 \\
\hline & $300-400$ & & - & 0.240 & 1.000 & 0.772 & \\
\hline & $400-500$ & & - & 1.000 & 0.261 & 0.992 & \\
\hline & $500-600$ & $\hat{0}$ & - & 0.736 & 0.985 & 0.199 & \\
\hline
\end{tabular}

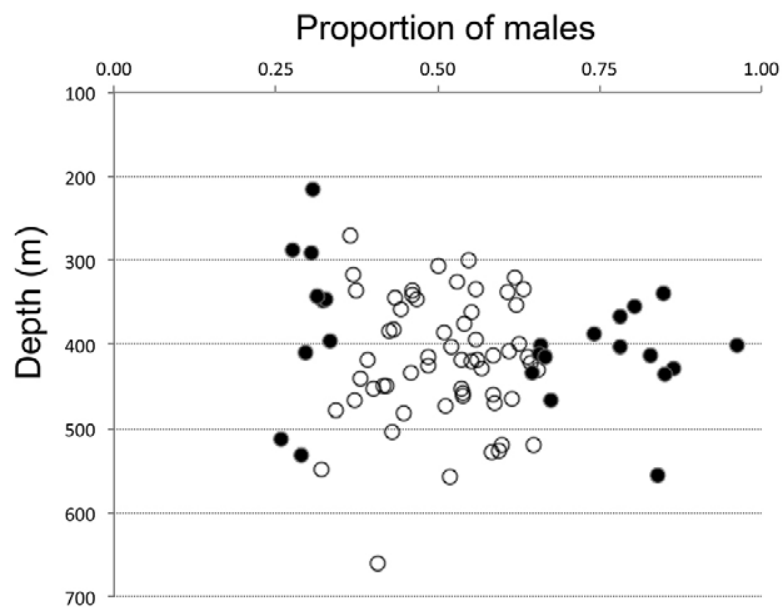

Fig. 8. - Sex ratio distribution of Pasiphaea sivado as a function of depth based on 84 valid samples. Black circles correspond to samples significantly different to the expected 1:1 sex ratio, while white circles indicate no significant difference in sex ratio.

and $17.9 \%$ towards males. The highest proportion of significant deviation towards females was found at the shallowest extreme of the bathymetric distribution of the species but also in the deepest strata. On the other hand, samples with a significantly higher proportion of males were located in the central depth strata. Overall, no significant tendency of gender segregation across the bathymetric distribution was found $(\mathrm{r}=0.0803$, $\mathrm{p}=0.4677$ ).

\section{DISCUSSION}

\section{Pleopod morphology}

The occurrence of sexual dimorphism in pleopod shape was detected in Pasiphaea sivado by both visualization and measurement methods: the traditional linear measurement and geometric morphometric analysis. An important, useful application of the present observations and the description of the occurrence of sexual dimorphism in pleopod shape in adult $P$. sivado is, from now on, the ability to quickly assess the gender of individuals when population biology studies are performed in the field.
A similar sexual dimorphism in pleopod shape has also been reported in Pasiphaea japonica, but it also seems to occur in Alainopasiphaea nudipeda, as evidenced by Figures 1 and 2d in Hayashi (1999), as well as in Pasiphaea semispinosa (authors' personal observations based on specimens deposited in collections: CBR at the ICM-CSIC in Barcelona and CCDE at the IEO-Cádiz). Other personal observations, not yet quantified, on the congeneric species Pasiphaea multidentata - a species that coexists with $P$. sivado across the Mediterranean Sea (Company et al. 2001, Abelló et al. 2002)—indicate that this species does not show this dimorphism.

The phylogenetic relationships within the family Pasiphaeidae are far from being properly understood (Hayashi 1999, 2006, Matzen da Silva et al. 2011). Based on present findings, the occurrence of sexual dimorphism in pleopod shape may well have a significant role in determining phylogenetic relationships within the family Pasiphaeidae, in particular within the $\mathrm{Pa}$ siphaea sivado group (Hayashi 1999, 2006), since both $P$. sivado and $P$. japonica (which also belongs to this group) have been shown to display this morphological characteristic (Doi 1975, Nanjo and Ohtomi 2009). Insufficient information is as yet available concerning other species in the genus or the family.

\section{Size dimorphism and sex ratio}

The present study also provides evidence on the occurrence of significant size dimorphism in $P$. sivado between genders, a fact previously unreported in this species, with females accumulating in size classes smaller than around $20 \mathrm{~mm}$ CL and males accumulating in the largest size classes. Sex ratio as a function of size clearly suggests the occurrence of differential growth rates between genders in $P$. sivado, as reported in many species of crustaceans (Abelló and Cartes 1992, Kevrekidis and Thessalou-Legaki 2006, Oh et al. 2006). This fact is usually attributed to a higher investment of females in reproduction rather than growth. This pattern appears to follow the so-called anomalous pattern described by Wenner (1972), in which no differences in sex ratio occur in juveniles, so a predominance of females is due to a lower female growth rate, with males finally accumulating their frequency in the largest sizes. Several explanations may account for this pattern, with different growth rates between the genders from the puberty moult or size at maturity being the most likely (Ben Mariem 2004, Fantucci et al. 2009). In the present study, mature females were identified at sizes larger than around $15 \mathrm{~mm} \mathrm{CL}$, coinciding with results from Company et al. (2001), and size at $50 \%$ maturity was found to vary geographically between $20.6 \mathrm{~mm}$ CL in the Catalan Sea and $23.0 \mathrm{~mm}$ $\mathrm{CL}$ in the Alboran Sea. Some biological characters estimated by Company et al. (2001) for P. sivado in the Catalan Sea support the sex ratio pattern with size reported in the present study. In that work males showed a faster growth rate $(\mathrm{k}=0.62)$, a larger asymptotic size $\left(\mathrm{L}_{\infty}=27.5 \mathrm{~mm}\right)$ and a higher growth performance index $(\Phi=0.13)$ than females $(0.55,26 \mathrm{~mm}$ and 0.06 , respec- 
tively). Reproductive aspects of the species, such as the continuous reproduction throughout the year and the higher volumetric index of females (2.92) compared with males (2.76) (Company et al. 2001), also suggest the smaller amount of energy investment in size growth by $P$. sivado females in relation to males. Another factor that may also limit growth in females is the moulting delay of ovigerous females in order to avoid loss of attached embryos, a phenomenon characteristic of crustacean species with egg-carrying biological features (Guerao et al. 1994, Oh et al. 1999, Viegas et al. 2007), such as caridean shrimps, lobsters, and brachyuran and anomuran crabs.

The size at which differences in sex ratio become significant has also been suggested to be an indirect indicator of the size at puberty moult and/or maturity size/age of the species (Abelló et al. 1990). In the present study, the precise size at which males outnumbered females progressively decreased from the Alboran Sea to the Alacant area and the Catalan Sea, corroborating the patterns of size structure and size at maturity observed in this area (Simão et al. 2015) and implying the occurrence of environmental and ecological processes affecting growth rates.

Overall, no significant gender segregation in $P$. sivado populations as a function of depth was found, suggesting that this species does not perform differential migration between sexes over the sea bottom. In the Catalan Sea, the absence of gender segregation by depth was also reported by Company et al. (2001) throughout the year, and could be related to the gregarious behaviour of macroplankton/micronekton organisms (McManus and Woodson 2012). During the daytime, $P$. sivado inhabits the epi-/suprabenthic environment over the upper and medium slope, with high densities recorded when sampled by demersal trawl nets during fishery research surveys (Cartes et al. 2007, García-Rodríguez et al. 2011, Simão et al. 2015), while during the night the species has been reported to migrate several hundred metres up the water column to waters near the surface to feed on plankton (Froglia and Giannini 1982, Cartes 1993, Simão et al. 2014).

Controversially, a relatively high number of samples showed biased sex ratios, towards both a higher proportion of males and of females. In the absence of direct observations, sex ratio-deviated groups, indicative of aggregative behaviour within genders, are suggestive of differential reproductive behaviour and/ or selective feeding in relation to the energetics and quality needs depending on gonadal developmental stages. An increase in stomach fullness and dietary energy intake has been recorded in pre-reproductive females of the deep-sea shrimp Aristeus antennatus, parallel to a significant increase of the gonadosomatic index and fecundity (Cartes et al. 2008). Differences in diet composition between genders and maturity stages have also been found in other shrimps, Plesionika heterocarpus and Plesionika martia (Fanelli and Cartes 2008). Aggregative behaviour within genders has also been related to other causes, such as the need to look for appropriate habitat for moulting (Reid et al. 1994, 1997, Sampedro and González-Gurriarán 2004) or for hatching (i.e. females look for suitable sites to improve dispersal and survival of recently hatched larvae) (Hicks 1985, Zeng and Naylor 1997, Carr et al. 2004). Survival of larvae may also be related to larval aggregation behaviour in addition to dispersal patterns, which are assumed to be low given the large size of the eggs and lower number of embryos that $P$. sivado females carry, when compared with other caridean shrimps (Company et al. 2001).

In attention to the concept of operational sex ratio (OSR), defined as the proportion of receptive females to sexually active males (Correa and Thiel 2003), the results of the present study suggest that the populations of $P$. sivado may overall be close to the OSR optima. The histograms of Figure 6 show that the overall shape of the SFDs of males and females is very similar, but males are displaced towards the right (largest sizes) by just one size class. If we quantify the total adult males and females bigger than the size class preceding the one in which the sex ratio starts to be biased towards males, we will find a sex ratio close to equilibrium. Even with the existence of a size sexual dimorphism or some samples with biased sex ratio, no overall sex segregation at population level was found.

The present study has shown the occurrence of morphological differences between genders in the benthopelagic shrimp $P$. sivado, namely in the pleopod shape of adult individuals. This characteristic has been shown to be useful for determining sex in field studies. Additionally a slight size dimorphism has been identified, as well as geographic population differences in size structure. This knowledge may also be useful for studying population biology patterns in still poorly-known species inhabiting exploited demersal ecosystems.

\section{ACKNOWLEDGEMENTS}

The authors are grateful to all participants in the MEDITS_ES cruises for all the help and facilities provided. Special thanks are due to A. Carbonell, $\mathrm{H}$. Gallardo, E. León, E. Marco-Herrero, E. Mayo, M. Rufino, P. Torres, E. Zas and many others who provided assistance on all cruises. We also thank Drs. G. Guerao, and J.E. Cartes for their comments. D.S. Simão acknowledges the pre-doctoral fellowship support by the Spanish Agency for International Cooperation and Development (AECID), Ministry of Foreign Affairs and Cooperation.

\section{REFERENCES}

Abelló P., Cartes J.E. 1992. Population characteristics of the deepsea lobsters Polycheles typhlops and Stereomastis sculpta (Decapoda: Polychelidae) in a bathyal mud community of the Mediterranean Sea. Mar. Biol. 114: 109-117.

Abelló P., Pertierra J.P., Reid D.G. 1990. Sexual size dimorphism, relative growth and handedness in Liocarcinus depurator and Macropipus tuberculatus (Brachyura: Portunidae). Sci. Mar. 54: 195-202.

Abelló P., Carbonell A., Torres P. 2002. Biogeography of epibenthic crustaceans on the shelf and upper slope off the Iberian Peninsula Mediterranean coasts: implications for the establishment of natural management areas. Sci. Mar. 66 (Suppl. 2): 183-198.

Aguzzi J., Company J.B., Abelló P., et al. 2007. Ontogenetic 
changes in vertical migratory rhythms of benthopelagic shrimps Pasiphaea multidentata and P. sivado. Mar. Ecol. Progr. Ser. 335: $167-174$

https://doi.org/10.3354/meps335167

Ben Mariem S. 2004. Première approche de la croissance de $P e$ naeus kerathurus (Decapoda Penaeidae) dans le golfe de Gabes, Tunisie. Crustaceana 68: 583-596 https://doi.org/10.1163/156854095X01763

Bertrand J.A., Gil de Sola L., Papaconstantinou C., et al. 2000. An international bottom trawl survey in the Mediterranean: the MEDITS programme. Actes de Colloques IFREMER 26:76-93.

Bertrand J., Gil de Sola L., Papaconstantinou C., et al. 2002. The general specifications of the MEDITS surveys. Sci. Mar. 66S2: 9-17.

Carr S.D., Tankersley R.A., Hench J.L., et al. 2004. Movement patterns and trajectories of ovigerous blue crabs Callinectes sapidus during the spawning migration. Estuar. Coast. Shelf Sci. 60: 567-579. https://doi.org/10.1016/j.ecss.2004.02.012

Cartes J.E. 1993. Feeding habits of pasiphaeid shrimps close to the bottom on the western Mediterranean slope. Mar. Biol. 117: 459-468.

Cartes J.E., Sardá F., Company J.B., et al. 1993. Day-night migrations by deep-sea decapod crustaceans in experimental sampling in the Western Mediterranean sea. J. Exp. Mar. Biol. Ecol. 171: 63-73. https://doi.org/10.1016/0022-0981(93)90140-J

Cartes J.E., Serrano A., Velasco F., et al. 2007. Community structure and dynamics of deep-water decapod assemblages from Le Danois Bank (Cantabrian Sea, NE Atlantic): Influence of environmental variables and food availability. Prog. Oceanog. 75: $797-816$. https://doi.org/10.1016/j.pocean.2007.09.003

Cartes J.E., Papiol V., Guijarro B. 2008. The feeding and diet of the deep-sea shrimp Aristeus antennatus off the Balearic Islands (Western Mediterranean): Influence of environmental factors and relationship with the biological cycle. Prog. Oceanogr. 79: $37-54$ https://doi.org/10.1016/j.pocean.2008.07.003

Clarke A., Holmes L.J. 1987. Notes on the biology and distribution of Pasiphaea species from the Southern Ocean. Br. Antarct. Surv. Bull. 74: 17-30

Company J.B., Cartes J.E., Sardá F. 2001. Biological patterns and near-bottom population characteristics of two pasiphaeid decapod crustacean species, Pasiphaea sivado and P. multidentata, in the north-western Mediterranean Sea. Mar. Biol. 139: 61-73. https://doi.org/10.1007/s002270100538

Correa C., Thiel M. 2003. Mating systems in caridean shrimp (Decapoda Caridea) and their evolutionary consequences for sexual dimorphism and reproductive biology. Rev. Chil. Hist. Nat. 76: 187-203. https://doi.org/10.4067/S0716-078X2003000200006

De Grave S., Fransen C.H.J.M. 2011. Carideorum Catalogus: The Recent Species of the Dendrobranchiate, Stenopodidean, Procarididean and Caridean Shrimps (Crustacea: Decapoda). Zool. Meded. Leiden 85: 195-588.

Doi S. 1975. Notes on Pasiphaea in Toyama Bay. Japan Sea Reg. Fish. Res. News 285: 1-6

Fanelli E., Cartes J.E. 2008. Spatio-temporal changes in gut contents and stable isotopes in two deep Mediterranean pandalids: influence on the reproductive cycle. Mar. Ecol. Prog. Ser. 355: 219-233. https://doi.org/10.3354/meps07260

Fantucci M.Z., Biagi R., Mantelatto F.L. 2009. Use of pleopod morphology to determine sexual dimorphism and maturity in hermit crabs: Isocheles sawayai as a model. Helgol. Mar. Res. 63: $169-175$. https://doi.org/10.1007/s10152-009-0144-0

Fiorentini L., Dremière P.Y., Leonori I., et al. 1999. Efficiency of the bottom trawl used for the Mediterranean international trawl survey (MEDITS). Aquat. Living. Resour. 12: 187-205. https://doi.org/10.1016/S0990-7440(00)88470-3

Frank T.M. 2000. Temporal resolution in mesopelagic crustaceans. Phil. Trans. R. Soc. Lond. B 355: 1195-1198. https://doi.org/10.1098/rstb.2000.0666

Froglia C., Giannini S. 1982. Osservazioni sugli spost amenti verticali nictomerali di Sergestes arcticus Kröyer e Sergia robusta (Smith) in Mediterraneo (Decapoda, Sergestidae). Atti Convegno UU.OO. afferenti ai Sottopragetti Risorse biologiche e Inquinamento, P.F. Oceanografia e fondi Marini: 311-319.
García-Rodríguez M., Abelló P., Fernández A., et al. 2011. Demersal assemblages on the soft bottoms off the Catalan-Levante coast of the Spanish Mediterranean. J. Mar. Biol. 2011: 1-16. https://doi.org/10.1155/2011/976396

Gibbons M.J., Macpherson E., Barangé M. 1994. Some observations on the pelagic decapod Pasiphaea semispinosa Holthuis 1951 in the Benguela upwelling system. S. Afr. J. Marine. Sci. 14: 59-67. https://doi.org/10.2989/025776194784287157

Guerao G., Pertez-Baquera J., Ribera C. 1994. Growth and reproductive biology of Palaemon xiphias Risso, 1816 (Decapoda: Caridea: Palaemonidae). J. Crustac. Biol. 14: 280-288. https://doi.org/10.2307/1548908

Hayashi K.I. 1999. Crustacea Decapoda: Revision of Pasiphaea sivado (Risso, 1816) and related species, with descriptions of one new genus and five new species (Pasiphaeidae). Mem. Mus. Nat. Hist. Nat. 180: 267-302.

Hayashi K.I. 2006. A new species of the Pasiphaea sivado species group from Taiwan (Decapoda, Caridea, Pasiphaeidae). Zoosystema 28: 341-346.

Hicks J.W. 1985. The breeding behaviour and migrations of the terrestrial crab Gecarcoidea natalis (Decapoda, Brachyura). Aust. J. Zool. 33: 127-142. https://doi.org/10.1071/ZO9850127

Iwasaki N. 1990. Pasiphaeid shrimps from the eastern North Atlantic and the Caribbean Sea, with the description of a new species of Pasiphae (Crustacea, Decapoda, Pasiphaeidae). Zool. Meded. Leiden 63: 187-203.

Johnsen S. 2005. The red and the black: Bioluminescence and the color of animals in the deep sea. Integr. Comp. Biol. 45: 234-246. https://doi.org/10.1093/icb/45.2.234

Kevrekidis K., Thessalou-Legaki M. 2006. Catch rates, size structure and sex ratio of Melicertus kerathurus (Decapoda: Penaeidae) from an Aegean Sea trawl fishery. Fish Res. 80: 270-279. https://doi.org/10.1016/j.fishres.2006.04.001

Klingenberg C.P. 2011. MorphoJ: an integrated software package for geometric morphometrics. Mol. Ecol. Resour. 11: 353-357. https://doi.org/10.1111/j.1755-0998.2010.02924.x

Klingenberg C.P., McIntyre G.S. 1998. Geometric morphometrics of developmental instability: analyzing patterns of fluctuating asymmetry with procrustes methods. Evolution 52: 1363-1375. https://doi.org/10.2307/2411306

Komai T., Lin C.W., Chan T.Y. 2012. Bathypelagic shrimps of the genus Pasiphaea (Decapoda: Caridea: Pasiphaeidae) from waters around Taiwan, with descriptions of four new species. J. Crust. Biol. 32: 295-325. https://doi.org/10.1163/193724011x615550

Lleonart J., Salat J. 1992. VIT, programa de análisis de pesquerías. Inf. Téc. Sci. Mar. 168-169: 1-116.

Matzen da Silva J., Creer S., Dos Santos A., et al. 2011. Systematic and evolutionary insights derived from mtDNA COI barcode diversity in the Decapoda (Crustacea: Malacostraca). PLoS ONE 6: e19449. https://doi.org/10.1371/journal.pone.0019449

McManus M.A., Woodson C.B. 2012. Plankton distribution and ocean dispersal. J. Exp. Biol. 215: 1008-1016. https://doi.org/10.1242/jeb.059014

Nanjo N. 2007. Feeding habits of the glass shrimp Pasiphaea japonica in Toyama Bay of the Sea of Japan. Crustac. Res. 36: 45-51.

Nanjo N., Ohtomi J. 2009. Reproductive biology of Pasiphaea japonica females in Toyama Bay, central Japan. Fisheries Sci. 75: 1189-1195. https://doi.org/10.1007/s12562-009-0154-5

Oh C.W., Hartnoll R.G., Nash R.D.M. 1999. Population dynamics of the common shrimp, Crangon crangon (L.), in Port Erin Bay, Isle of Man, Irish Sea. ICES J. Mar. Sci. 56: 718-733. https://doi.org/10.1006/jmsc.1999.0501

Oh C.W., Kim J.Y., Jeong I.J., et al. 2006. Reproduction and population dynamics of Leptochela gracilis (Decapoda: Pasiphaeidae) on the western coast of Korea, Yellow Sea. J. Mar. Biol. Ass. UK. 86: 113-120. https://doi.org/10.1017/S0025315406012914

Ramirez-Llodra E., Company J.B., Camps M., et al. 2007. Spatiotemporal variations in reproductive patterns and population structure of Pasiphaea multidentata (Decapoda: Caridea) in the Blanes canyon and adjacent margin, Northwestern Mediterranean Sea. Mar. Ecol. Evol. Perspect. 28: 470-479. https://doi.org/10.1111/j.1439-0485.2007.00207.x

Reid D.G., Abelló P., Warman C.G., et al. 1994. Size-related mat- 
ing success in the shore crab Carcinus maenas (Crustacea: Brachyura). J. Zool. Lond. 232: 397-407. https://doi.org/10.1111/j.1469-7998.1994.tb01581.x

Reid D.G., Abelló P., Kaiser M.J., et al. 1997. Carapace colour, intermoult duration and the behavioural and physiological ecology of the shore crab Carcinus maenas. Est. Coast. Shelf Sci. 44: 203-211.

https://doi.org/10.1006/ecss.1996.0212

Rohlf F.J. 2010a. TpsDig, digitize landmarks and outlines, version v2.16. Department of Ecology and Evolution, State University of New York at Stony Brook.

Rohlf F.J. 2010b. TpsRelw, relative warps analysis, version 1.49 Department of Ecology and Evolution, State University of New York at Stony Brook.

Sampedro M.P., González-Gurriarán E. 2004. Aggregating behaviour of the spider crab Maja squinado in shallow waters. J. Crust. Biol. 24: 168-177. https://doi.org/10.1651/C-2404

Simão D.S., Torres A.P., Olivar M.P., et al. 2014. Vertical and temporal distribution of pelagic decapod crustaceans over the shelfbreak and middle slope in two contrasting zones around Mallorca (western Mediterranean Sea). J. Mar. Syst. 138: 139-149. https://doi.org/10.1016/j.jmarsys.2013.10.008

Simão D.S., Zas E., Carbonell A., et al. 2015. Pasiphaeid shrimps in the western Mediterranean: geographical variability in distribution and population patterns. Sci. Mar. 79: 199-209. https://doi.org/10.3989/scimar.04147.07a
Sokal R.R., Rohlf F.J. 1981. Biometry, 2nd edition. W.H. Freeman \& Co., New York.

Tavares C.R., Cardoso I.A. 2006. Deep-sea Pasiphaeidae (Crustacea: Decapoda: Caridea) from off the Brazilian central coast between 11 degrees and 22 degrees S, collected by the Revizee Program. Zootaxa 1174: 27-39.

Viegas I., Martinho F., Neto J., et al. 2007. Population dynamics, distribution and secondary production of the brown shrimp Crangon crangon (L.) in a southern European estuary. Latitudinal variations. Sci. Mar. 71: 451-460. https://doi.org/10.3989/scimar.2007.71n3451

Viscosi V., Cardini A. 2011. Leaf morphology, taxonomy and geometric morphometrics: a simplified protocol for beginners. PLoS ONE 6: e25630. https://doi.org/10.1371/journal.pone.0025630

Wenner A.M. 1972. Sex ratio as a function of size in marine Crustacea. Am. Nat. 106: 321-350. https://doi.org/10.1086/282774

Zariquiey Álvarez R. 1957. Decápodos españoles XIII - Las Pasiphaeas del Mediterráneo occidental. Trabajos del Museo de Zoología Nueva Serie Zoológica 2: 1-41.

Zariquiey Álvarez R. 1968. Crustáceos decápodos ibéricos. Inv. Pesq. 32: 1-510.

Zeng C., Naylor E. 1997. Rhythms of larval release in the shore crab Carcinus maenas (Decapoda: Brachyura). J. Mar. Biol. Ass. U.K. 77: 451-461.

https://doi.org/10.1017/S0025315400071794 